\title{
Borehole depth determination to freshwater and well design using geophysical logs in coastal regions of Lagos, southwestern Nigeria
}

\author{
A. A. Akinlalu ${ }^{1}$ - D. O. Afolabi ${ }^{1}$ \\ Received: 19 March 2018 / Accepted: 4 September 2018 / Published online: 11 September 2018 \\ (c) The Author(s) 2018
}

\begin{abstract}
The determination of depth to freshwater aquifers and lack of geophysical borehole log data to help borehole developers in the design of borehole have long been identified as a problem in coastal areas. This necessitates a study of the coastal environment of Lagos, southwestern Nigeria, to determine the depth to freshwater and give recommendation on the borehole design during installation stage that can be projected to areas immediate to where geophysical logs are available. For this study, twenty geophysical log data were utilized which are spread across Ikoyi, Victoria Island and Lekki of Lagos metropolis. The study shows that the saline water extent in Ikoyi, Victoria Island and Lekki occurs to an average depth of 146, 154 and $162 \mathrm{~m}$, respectively. Relative variation in quality of water across the regions is because of the differences in the thickness of clay units serving as protective units separating the polluted zones from the unpolluted zones. It is recommended that water wells in Ikoyi, Victoria Island and Lekki be drilled to an approximate depth of $240 \mathrm{~m}$ and the last $18 \mathrm{~m}$ be screened. This research work was able to develop a design model for the boreholes located in the Island. The model includes gravel packing thickness of about $50 \mathrm{~m}$ from the bottom of the hole and cement grouting to the surface of the borehole to avoid the contamination of the borehole.
\end{abstract}

Keywords Freshwater $\cdot$ Grouting $\cdot$ Gravel packing $\cdot$ Lagos $\cdot$ Aquifers $\cdot$ Borehole log

\section{Introduction}

The major challenge of groundwater development in coastal environment is saltwater intrusion into freshwater-bearing aquifers (Adeoti et al. 2010). Saltwater intrusion into the coastal aquifers, especially in developed regions, has long been regarded as a major concern around the world. Introduction of saltwater of the smallest percentage into freshwater is enough to reduce its potability (Custodio 1987). The intrusion occurs as a result of the induced flow of seawater into freshwater aquifers. This is driven by a violation of the delicate hydrogeological balance that exists between freshwater and seawater in coastal aquifers due to large-scale groundwater abstraction occasioned by rapid urbanization around the coast (Longe et al. 1987; Barlow 2003; Goldman and Kafri 2004; Pareek et al. 2006; Adeoti et al. 2010). Due to the proximity of some regions to the Atlantic and Pacific

\section{A. A. Akinlalu}

aaakinlalu@futa.edu.ng

1 Department of Applied Geophysics, Federal University of Technology, Akure, Nigeria
Oceans, the general population is faced with problems of freshwater exploration from the subsurface. It is becoming more difficult for groundwater developers to construct boreholes in areas adjoining the sea or lagoon without encountering saltwater (Oladapo et al. 2014).

This has in turn increased the cost of developing water wells in these regions. Wells are drilled to great depth and geophysical borehole logging has to be carried out, which is expensive to obtain. This has brought about by the use of other geophysical methods like electrical resistivity, electromagnetic methods in the investigation of areas that are deemed problematic (Ayolabi et al. 2003; Adepelumi et al. 2008) and have proved relatively ineffective at times since they are indirect methods that depend on inferences from signal received at the surface unlike the geophysical logging method (Ayolabi et al. 2013).

Saltwater intrusion into aquifer units of freshwater has decreased the potability of water in coastal regions which necessitates the use of wireline geophysical logging equipments to delineate polluted zones and locate freshwater aquiferous layer of which acquisition of such data is expensive (Fligg and Rodrigues 1981; Keys 1990). The 
applicability of geophysical borehole logging in saltwater intrusion studies is brought about by its ability in lithologic differentiation, identification of salt-freshwater interface and place or places to be screened for freshwater abstraction in wells during well development.

Consequent upon this, there is need for precise exploitation and development of boreholes at low cost, which will meet the needs of various individuals.

Since the geology of Lagos is well studied and relatively uniform over fairly large areas (Jones and Hockey 1964; Omosuyi et al. 1999; Adeoti et al. 2010), a relatively precise estimation of depth to freshwater aquifer can be achieved through existing geophysical borehole logs in the environment. Also, the aquifer units that have been delineated from different studies in the area (Longe et al. 1987; Ayolabi et al. 2013) will serve as guide to proper estimation of depth to freshwater aquifer.

The relatively homogenous nature of the study area necessitates the need to employ geophysical logging tools such as natural gamma log (to infer lithology and to delineate sand unit) and resistivity log (to locate saltwater-freshwater interface and freshwater zone) since they give the true subsurface information because they probe very close to the formation.

These log data are expensive to obtain and are not readily available to geophysicists. This is because the geophysical logging tools are expensive to purchase and need expertise for data acquisition and interpretation of data which are not readily available. Moreover, wells need to be drilled before geophysical borehole logging data could be acquired.

Therefore, this study is aimed at reducing the challenges encountered in groundwater exploitation in coastal regions of Lagos metropolis through the use of existing borehole $\operatorname{logs}$ in predicting the average saltwater-freshwater interface, estimating depth to drill, lithologic units variation, placement of screens during borehole development and recommending buffer zones so that little cost will be expended in the exploitation of groundwater, especially in areas where the logs data are available.

\section{Description of the geology, hydrogeology and geomorphology of Lagos}

The Lagos metropolis is a zone of coastal creeks and lagoons (Pugh 1954; Adegoke 1977; Adepelumi et al. 2009), a region underlain by sedimentary deposits of the coastal plain sand also known as the Benin Formation (Fig. 1). The coastal plain sand is a member of the Dahomey Basin; the sedimentary basin which covers most parts of southwestern Nigeria. The coastal plain sand is composed essentially of sand, silt and clay. The location is devoid of geological structures such as fractures and lineaments which is to be expected in a noncrystalline terrain like the study area. The formation has a characteristic sequence of alternating sand and clay layers, and it is known to be multi-aquiferous (Jones and Hockey 1964; Adeyemi 1972; Omosuyi et al. 1999; Akomeno 2013). Reyment (1965) also described the lithologic and stratigraphic sequence in the Dahomey Basin. A lot of works have also been done on the biostratigraphy of the Dahomey Basin from which smaller geologic units of the Dahomey Basin were delineated (Fayose 1970; Ogbe 1972; Adegoke 1977; Awosika and Dublin-Green 1994; Oyedele 2001).

In the Island area, the surface geology of the study area is made up of the Benin Formation (Miocene to recent), recent littoral alluvial, lagoons and coastal plain sand deposits. The sand ranges in size from very fine to medium to coarse grained (Oteri 1988). The topography is generally low-lying and flat with several points at sea level. This makes the area prone to periodic flooding.

In the mainland area, the coastal plain sand is the outcropping formation overlying the Ilaro, Ewekoro Formation and the Abeokuta group.

Hydrogeologically, four major aquifers are recognized within the basin. Kampsax-Kruger and Sshwed Associates (1977) subdivided the aquifers in Lagos into four, with the first representing the recent sediments and the second and third aquifer being the coastal plain aquifer. The fourth aquifer represents the Abeokuta Formation. The surface aquifer is in the recent sediments, and two major aquifers are within the coastal plain sands. The most prolific aquifer is within the Abeokuta group (Longe et al. 1987; Onwuka 1990).

The last work by the Hydrogeological Investigation of Lagos State team as documented by Coode et al. (1996) confirmed that there are four main aquifers separated by clay layers.

Hill and Webb (1958) during their investigation observed that the salinity of the Lagos lagoon and the rivers emptying into them shows both diurnal fluctuation due to tidal effects and much greater seasonal changes caused by the influx of freshwater during the rainy season.

Allen (1965) drew a map from air photographs of the Lagos and Lekki area indicating the major rivers draining the southwestern part of Nigeria into the Lagos lagoon. Salinity was found to be high during the periods of January and May, fell in June and July but rose again in August and September only to fall once more in October and November.

\section{Materials and methods}

Twenty borehole logs were used for this study which are spread across some of the island areas of Lagos metropolis as shown in Figs. 2 and 3. Geologic profiles for boreholes oriented in the same direction are established along with locations surrounding the boreholes and are denoted as: A-A': Cameron-Mobolaji Johnson-Kingsway-Eboh; 


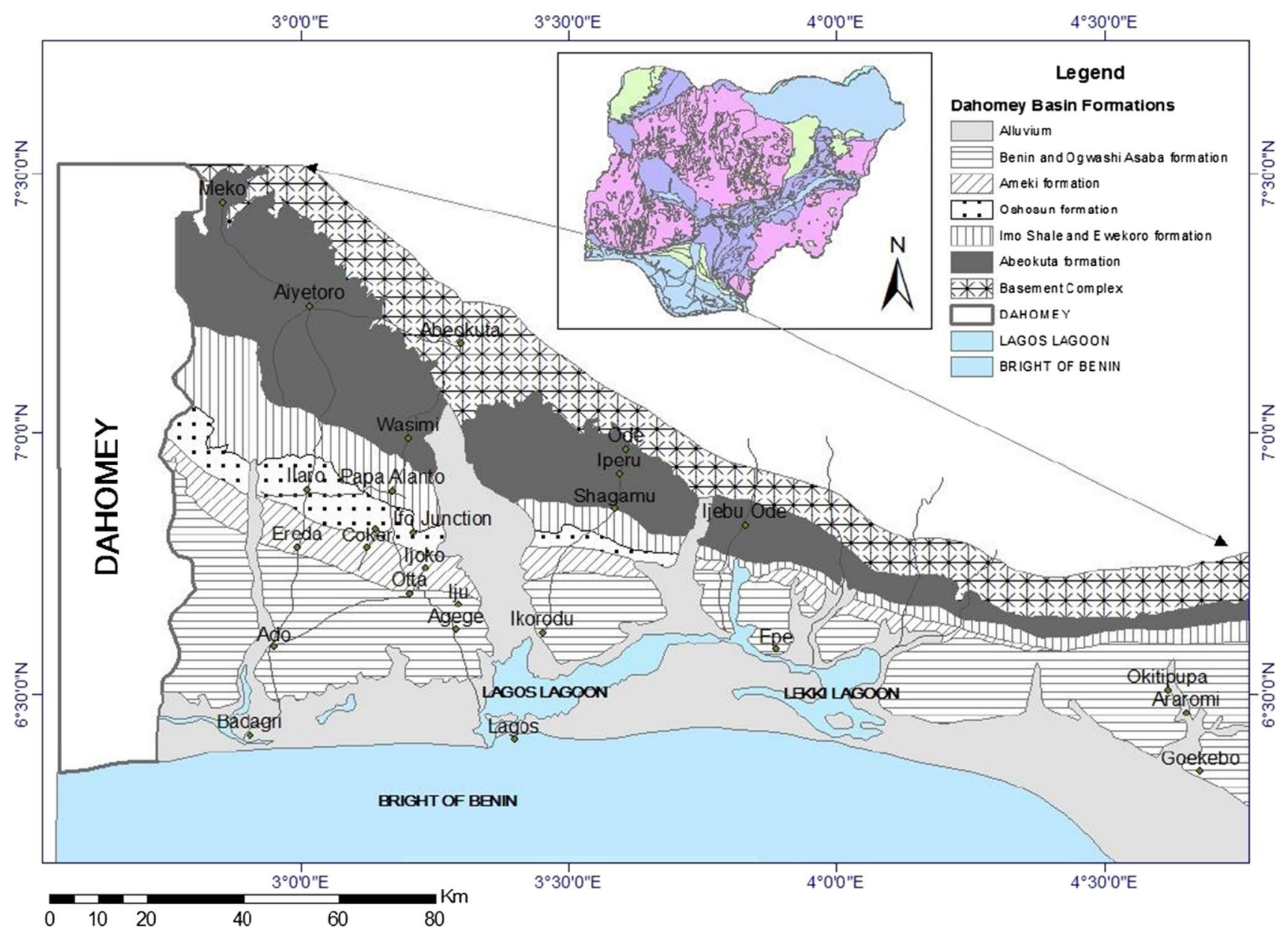

Fig. 1 Geological map of Lagos State, inset map of Nigeria (after NGSA 2015)

B-B': Association-Onilegbale-MacDonald-Bourdillon; C-C': Igodu-Freedom Road-Akanni Ajiran-Harmony; D-D': Unity-Lawal Silawal-Ologo; and E-E': Akanni Ajiran-Lawal Silawal-Lekki Beach road.

The logging tool utilized for the study consists of natural gamma $\log$ and the resistivity $\log \left(64^{\prime \prime}\right)$ to measure the resistivity of the uninvaded zone in the borehole.

The logs are interpreted to identify lithologies encountered in the boreholes, determine saltwater and freshwater interface, water quality and delineate freshwater zone and its thickness (Kwader 1986).

Every ore body has its resistance to the flow of current which is a parameter that is measured with the introduction of a known voltage through a sonde with the current rated according to the unit area expected to cover, called R8, R16, R32 and R64 in a water-filled hole (Schlumberger 1977; Hallenburg 1984; Schnoebelen et al. 1995; Chopra et al. 2005). The natural gamma radiation of the rock encountered is also measured with the same Sonde but with a different probe. The Sonde that measures the combined natural gamma and the resistivity is called ELGG (electrical resistivity log with gamma).

The acquired field data is (i.e., logs are being stored on the memory of the computer) through the logger software interface. The acquired data are then digitized using $1.0 \mathrm{~m}$ sampling interval, and then a digitized log is produced by using a computer application software known as Microsoft Excel to plot the curves.

The resistivity data presented on the logs were interpreted qualitatively based on the classification of Ibrahim (2008) shown in Table 1.

\section{Results and discussion}

The results of the study are presented as geo-sections and maps. The geo-sections enabled the identification of the various lithological units within the study area. The maps were utilized to determine the variation of depth of pollution and quality of water across the areas of investigation. 


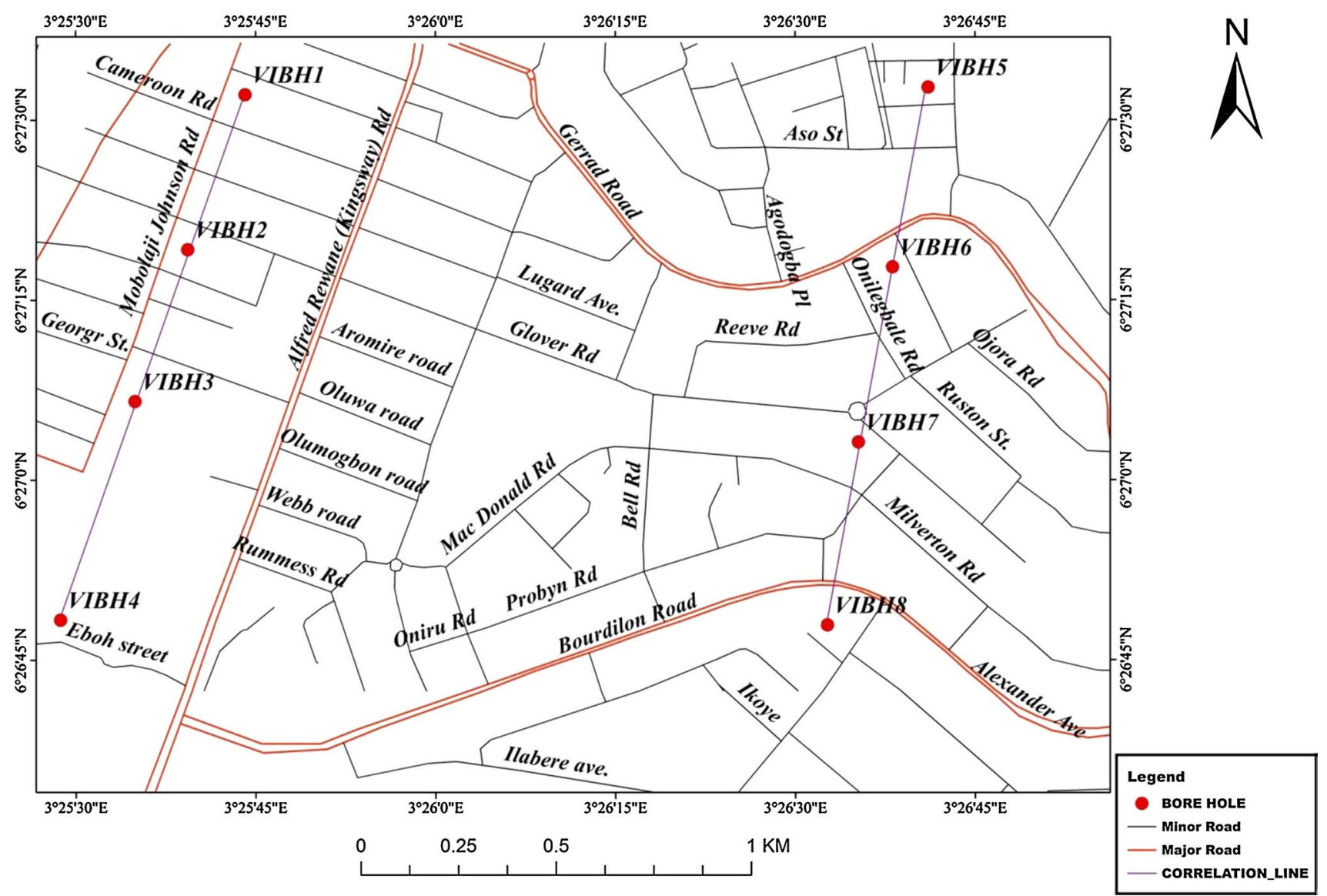

Fig. 2 Map showing borehole locations in Ikoyi-Victoria Island axis

The geophysical borehole logging data obtained showed that there is massive saline water incursion into freshwater aquifers affecting the potability of water in the top aquifer. Table 2 shows that the pollution is seen to occur to an average depth of $158 \mathrm{~m}$. The result of the data agrees with the assessment of Adeoti et al. (2010) who carried out a detailed work on Oniru part of Lekki axis using integrated geophysical survey methods; electrical resistivity, self-potential and induced polarization to monitor saltwater intrusion into freshwater aquifers. Lithologic plots in Figs. 4, 5, 6, 7 and 8 are modeled from the data obtained from the lithology and resistivity logs.

\section{Lithology and resistivity logs}

In Fig. 4, there is an observable progressive increase in the saline water incursion in the southern direction across VIBH1-VIBH4 toward the receding coastline. Figure 5 also shows similar trend across VIBH5-VIBH7, but with a distinction at VIBH8. This may be due to the fact that the areas around VIBH8 are less populated in comparison with other areas around VIBH1 to VIBH7. The vulnerability of aquifers in less-populated coastal areas of Lagos State is low due to the low pressure on the producing aquifers (Adeoti et al. 2010). This assertion is buttressed by the results obtained from the works of Gyopari (2005) in the highly populated areas in Manawatu, New Zealand. It was concluded that the densely populated areas are mostly at risk of contamination from saline intrusion because of the high volume of groundwater abstractions. Therefore, the resistivity data obtained provide a basis for future monitoring of the saline water/freshwater interface. Hence, the aquifers in the region around VIBH8 are not highly pressured by overpumping to tilt the delicate balance that exists between saltwater/freshwater interfaces. Nevertheless, regions around VIBH8 are more prone to contamination of saline water than regions around VIBH1 to VIBH7 because there is no protective layer such as clay or clayey sand/sandy clay to prevent contamination of the freshwater aquifers in the region. According to Ayolabi et al. (2013), the boreholes having thick clay units are found to be less prone to pollution from saltwater and waste disposal at the campus of the University of Lagos.

The freshwater sand is seen to start at an average depth of $156 \mathrm{~m}$. The thickness of the freshwater sand at depth of $156 \mathrm{~m}$ and above ranges from 7 to $32 \mathrm{~m}$ making it suitable for groundwater abstraction. 


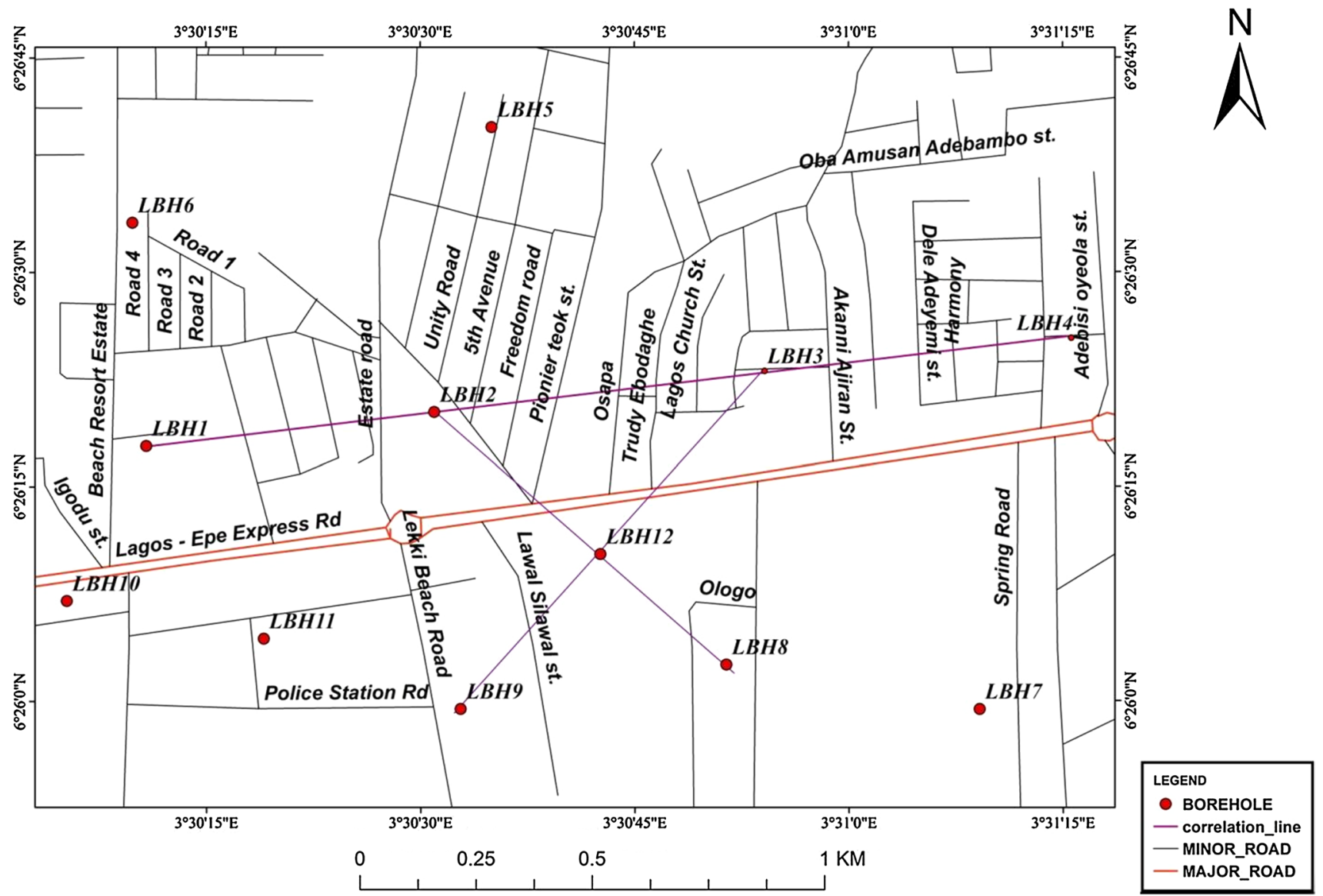

Fig. 3 Map showing borehole locations in Lekki axis

Table 1 Physical parameters of water in typical sedimentary environment (modified after Ibrahim 2008)

\begin{tabular}{lccl}
\hline & Resistivity $(\Omega \mathrm{m})$ & Conductivity $(\mathrm{mhos} / \mathrm{m})$ & Salinity $(\mathrm{mg} / \mathrm{l})$ \\
\hline Freshwater sand & $120-600$ & $40-83$ & $35-$ Very small \\
Saltwater sand & $0.1-40$ & $2500-100,000$ & $21,000-5000$ \\
Brackish water sand & $40-100$ & $1000-2500$ & $5000-1500$ \\
\hline
\end{tabular}

Figure 6 shows that the depth of contamination is increasing in the eastern direction across LBH1 to LBH4. The presence of clay, clayey sand/sandy clay serving as protective units for the freshwater sand is noticeably present in these regions with a gradual increase also in the eastern direction. Boreholes drilled to depth of $230 \mathrm{~m}$ or more in regions around LBH3 and LBH4 are less susceptible to contamination from saline water because of the presence of thicker protecting units separating the polluted zones from the unpolluted zones compared to the regions around LBH1 and LBH2. This is in accordance with the deduction of Phongpiyah and Helmut (2012), where they opined that thick clay units overlying freshwater sand in Southern Thailand prevent the immediate contamination of the freshwater sand by saltwater.
Figure 7 also reveals that the depth of contamination is almost the same across LBH2, LBH12 and LBH8. Regions around LBH2 and LBH12 are more prone to contamination for lack of thick protective unit to prevent the contamination of freshwater aquifers compared to regions around LBh8. Therefore, borehole depth of $230 \mathrm{~m}$ or more should be drilled in regions around $\mathrm{LBH} 2$ and $\mathrm{LBH} 12$ to prevent the risk of the productive freshwater sand aquifers being contaminated with saline water.

Similarly in Fig. 8, the depth of pollution is almost uniform across LBH3, LBH12 and LBH9. The longevity of the boreholes in this area is dependent majorly on the presence of a very thick clay unit serving as a protective layer between the unpolluted and polluted zone as observed in LBH9. This accounts for the failure of most boreholes in this 
Table 2 Interpretation summary of borehole logs along profiles A-A', B-B', C-C', D-D' and E-E'

\begin{tabular}{|c|c|c|c|c|c|c|c|}
\hline $\mathrm{BH}$ & Northings & Eastings & $\begin{array}{l}\text { Depth } \\
\text { logged } \\
\text { (m) }\end{array}$ & $\begin{array}{l}\text { Depth extent of } \\
\text { polluted zone }(\mathrm{m})\end{array}$ & $\begin{array}{l}\text { Average resistivity of } \\
\text { polluted zone }(\Omega \mathrm{m})\end{array}$ & $\begin{array}{l}\text { Average resistivity of } \\
\text { unpolluted zone }(\Omega \mathrm{m})\end{array}$ & $\begin{array}{l}\text { Average resistivity in } \\
\text { the borehole }(\Omega \mathrm{m})\end{array}$ \\
\hline VIBH1 & $6^{\circ} 27^{\prime} 32^{\prime \prime} \mathrm{N}$ & $3^{\circ} 25^{\prime} 45^{\prime \prime} \mathrm{E}$ & 233 & 134 & 90 & 268 & 178 \\
\hline VIBH2 & $6^{\circ} 27^{\prime} 19^{\prime \prime} \mathrm{N}$ & $3^{\circ} 25^{\prime} 41^{\prime \prime} \mathrm{E}$ & 231 & 142 & 33 & 246 & 115 \\
\hline VIBH3 & $6^{\circ} 27^{\prime} 08^{\prime \prime} \mathrm{N}$ & $3^{\circ} 25^{\prime} 37^{\prime \prime} \mathrm{E}$ & 236 & 152 & 38 & 305 & 136 \\
\hline VIBH4 & $6^{\circ} 26^{\prime} 49^{\prime \prime} \mathrm{N}$ & $3^{\circ} 25^{\prime} 21^{\prime \prime} \mathrm{E}$ & 235 & 156 & 42 & 153 & 106 \\
\hline VIBH5 & $6^{\circ} 27^{\prime} 34^{\prime \prime} \mathrm{N}$ & $3^{\circ} 26^{\prime} 41^{\prime \prime} \mathrm{E}$ & 252 & 152 & 39 & 252 & 124 \\
\hline VIBH6 & $6^{\circ} 27^{\prime} 20^{\prime \prime} \mathrm{N}$ & $3^{\circ} 26^{\prime} 39^{\prime \prime} \mathrm{E}$ & 236 & 156 & 37 & 156 & 137 \\
\hline VIBH7 & $6^{\circ} 27^{\prime} 05^{\prime \prime} \mathrm{N}$ & $3^{\circ} 26^{\prime} 36^{\prime \prime} \mathrm{E}$ & 237 & 168 & 52 & 172 & 97 \\
\hline VIBH8 & $6^{\circ} 26^{\prime} 45^{\prime \prime} \mathrm{N}$ & $3^{\circ} 26^{\prime} 34^{\prime \prime} \mathrm{E}$ & 231 & 152 & 46 & 238 & 135 \\
\hline LBH1 & $6^{\circ} 26^{\prime} 19^{\prime \prime} \mathrm{N}$ & $3^{\circ} 30^{\prime} 11^{\prime \prime} \mathrm{E}$ & 237 & 160 & 54 & 214 & 110 \\
\hline LBH2 & $6^{\circ} 26^{\prime} 20^{\prime \prime} \mathrm{N}$ & $3^{\circ} 30^{\prime} 32^{\prime \prime} \mathrm{E}$ & 230 & 161 & 32 & 137 & 66 \\
\hline LBH3 & $6^{\circ} 26^{\prime} 21^{\prime \prime} \mathrm{N}$ & $3^{\circ} 30^{\prime} 51^{\prime \prime} \mathrm{E}$ & 235 & 160 & 56 & 327 & 143 \\
\hline LBH4 & $6^{\circ} 26^{\prime} 23^{\prime \prime} \mathrm{N}$ & $3^{\circ} 31^{\prime} 15^{\prime \prime} \mathrm{E}$ & 248 & 162 & 52 & 286 & 132 \\
\hline LBH5 & $6^{\circ} 26^{\prime} 40^{\prime \prime} \mathrm{N}$ & $3^{\circ} 30^{\prime} 35^{\prime \prime} \mathrm{E}$ & 230 & 162 & 22 & 195 & 72 \\
\hline LBH6 & $6^{\circ} 26^{\prime} 32^{\prime \prime} \mathrm{N}$ & $3^{\circ} 30^{\prime} 09^{\prime \prime} \mathrm{E}$ & 230 & 160 & 39 & 282 & 119 \\
\hline LBH7 & $6^{\circ} 25^{\prime} 57^{\prime \prime} \mathrm{N}$ & $3^{\circ} 31^{\prime} 11^{\prime \prime} \mathrm{E}$ & 216 & 164 & 49 & 195 & 87 \\
\hline LBH8 & $6^{\circ} 26^{\prime} 02^{\prime \prime} \mathrm{N}$ & $3^{\circ} 30^{\prime} 52^{\prime \prime} \mathrm{E}$ & 248 & 164 & 52 & 308 & 143 \\
\hline LBH9 & $6^{\circ} 25^{\prime} 54^{\prime \prime} \mathrm{N}$ & $3^{\circ} 30^{\prime} 35^{\prime \prime} \mathrm{E}$ & 247 & 166 & 53 & 294 & 142 \\
\hline LBH10 & $6^{\circ} 26^{\prime} 06^{\prime \prime} \mathrm{N}$ & $3^{\circ} 30^{\prime} 05^{\prime \prime} \mathrm{E}$ & 210 & 163 & 58 & 240 & 102 \\
\hline LBH11 & $6^{\circ} 26^{\prime} 04^{\prime \prime} \mathrm{N}$ & $3^{\circ} 30^{\prime} 17^{\prime \prime} \mathrm{E}$ & 220 & 166 & 49 & 220 & 93 \\
\hline LBH12 & $6^{\circ} 26^{\prime} 08^{\prime \prime} \mathrm{N}$ & $3^{\circ} 30^{\prime} 43^{\prime \prime} \mathrm{E}$ & 225 & 164 & 85 & 235 & 131 \\
\hline
\end{tabular}

region (Oyedele 2001). Regions around LBH3 and LBH12 have a relatively thin protective layer. Hence, the aquifers can be easily contaminated when overpressured by overpumping. Borehole drilled to depth of $230 \mathrm{~m}$ or more in the region would have freshwater aquifers at depth of $220 \mathrm{~m}$ to be safe from saline water incursion, provided pressure is not induced in the boreholes by overpumping.

\section{Geoelectric sections}

Five sections denoted as $\mathrm{A}-\mathrm{A}^{\prime}$ to $\mathrm{E}-\mathrm{E}^{\prime}$ were generated across the study area.

\section{Geosection A-A' (Cameron-Mobolaji Johnson- Kingsway-Eboh)}

Figure 4 shows the correlation panel of boreholes VIBH1, VIBH2, VIBH3 and VIBH4 oriented in the approximate North-South direction. The topmost layer is made up of sand unit typical of alluvium deposit. VIBH4 has more sandy clay and clay than the rest of the borehole indicating the increase in content and thickness of clay in the southern direction. The clay unit is seen to increase from VIBH1 to VIBH4 with major occurrence at VIBH4. Groundwater can be easily abstracted from VIBH1 and VIBH2 due to the thickness range of the sand unit in the boreholes. The first few meters of VIBH3 and VIBH4 will pose serious problems to groundwater developers because of the constitution of clay there in terms of drilling.

The correlation panel shows that the saline water/freshwater interface is increasing in the southern direction. A protective layer to separate the polluted region from the immediate unpolluted region like clay or sandy clay is present in VIBH1, VIBH2 and VIBH3 but absent in VIBH4. The depth extent of pollution is seen to increase southwards in this axis. This shows that freshwater aquifers in VIBH4 are prone to contamination. Therefore, screens would have to be placed at depth of about $230 \mathrm{~m}$. Boreholes in this region are to be screened at a depth range of 220 and $235 \mathrm{~m}$ for domestic and industrial use.

\section{Geosection B-B' (Association-Onilegbale- MacDonald-Bourdillon)}

Figure 5 shows the correlation panel of VIBH5, VIBH6, VIBH7 and VIBH8 oriented in the approximate north-south direction. The region has lots of clay with its clay content decreasing in the southern direction. The first few meters of VIBH5 and VIBH6 are made up of mostly clay. The depth to saline water intrusion in this axis is at an average of $138 \mathrm{~m}$. In this axis, clay unit is predominant at VIBH5 and VIBH6 in the upper meters of the boreholes. The clay unit is seen to 


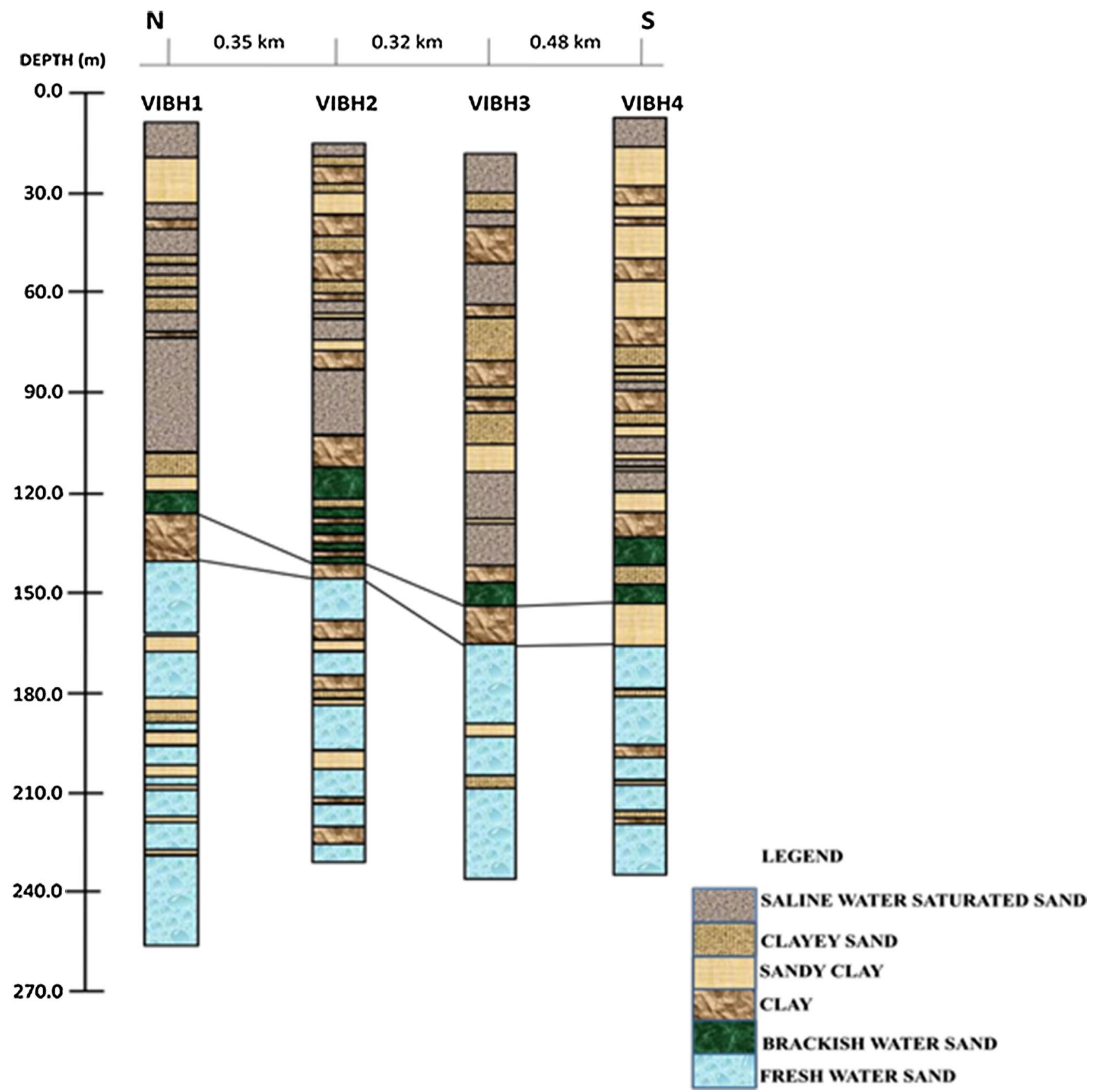

Fig. 4 Correlation panel of geosection $\mathrm{A}-\mathrm{A}^{\prime}$ showing the occurrence of the end of polluted sand unit and the beginning of freshwater sand unit

decrease across the boreholes in the eastern direction. Drilling will be difficult in this region as a result of the presence of clay unit in the upper meters. Also, the absence of sand units in the upper meters means that the boreholes in the region need to be drilled to a depth of about $210 \mathrm{~m}$ where there is a considerable thickness of sand units.

The saline water/freshwater interface is seen to be increasing in the southern direction, but sharply decreasing on getting to VIBH8. Sandy clay, clayey sand unit serving as a protective layer for the unpolluted zone is seen to decrease in the southern direction with a total absence at VIBH8.

There is an absence of protective layer to separate the polluted area from the unpolluted area. This makes deeper freshwater aquifers in VIBH8 to be very prone to contamination. Therefore, special care has to be taken in the development of groundwater at the point where VIBH8 is located. Also, groundwater use at this point will have a limited use as frequent pumping will induce saline water flow into the 


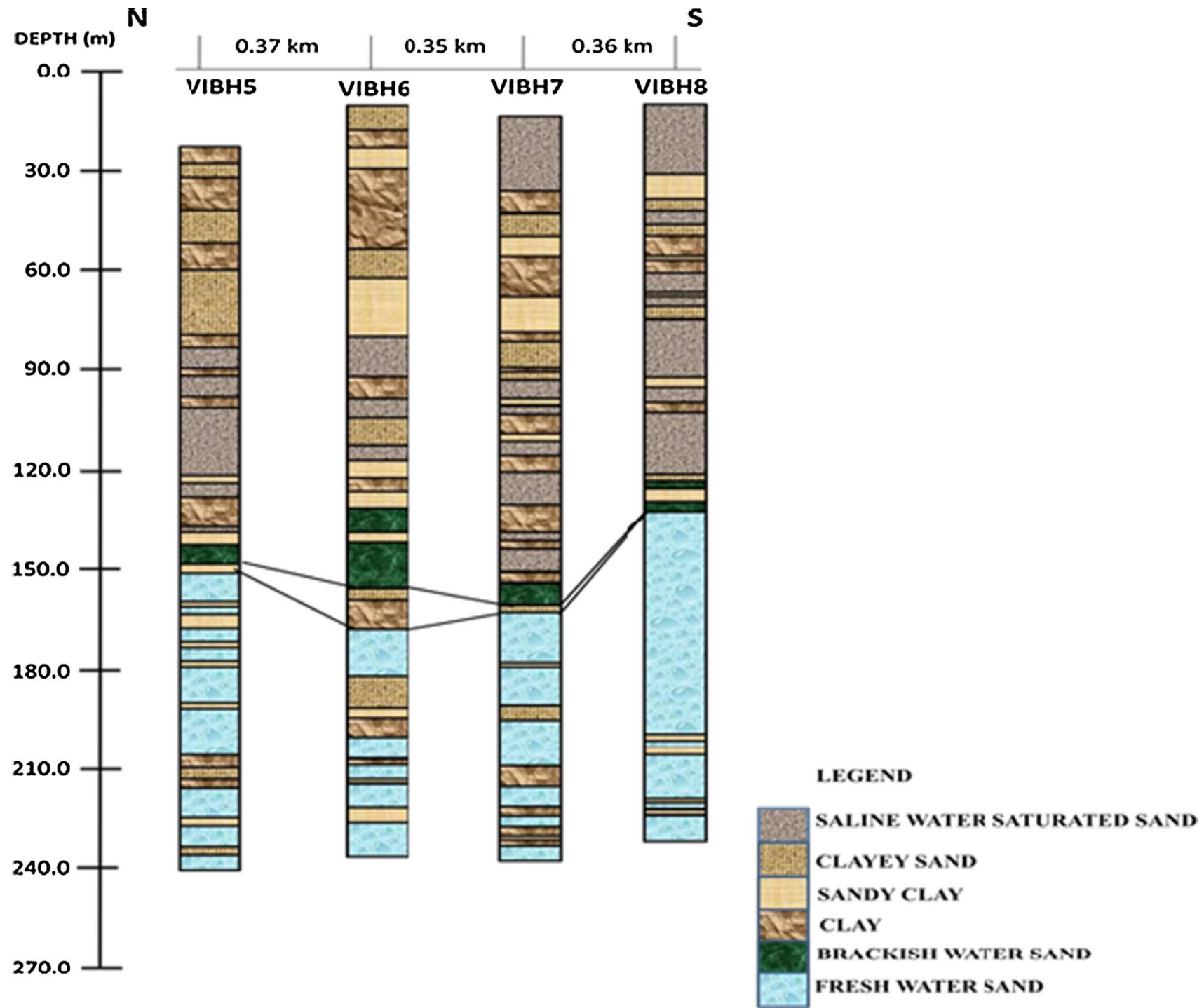

Fig. 5 Correlation panel of geosection B-B' showing the occurrence of the end of polluted sand unit and the beginning of freshwater sand unit

freshwater aquifers. Generally, boreholes in this area can be drilled to a depth of about $225 \mathrm{~m}$ or more.

\section{Geosection C-C' (Igodu-Freedom Road-Akanni Ajiran-Harmony)}

Figure 6 shows the correlation panel of LBH1, LBH2, LBH3 and LBH4 oriented in the approximate west-east direction. The sand unit in this region is decreasing gradually in the eastern direction along the reclaimed peninsula. This is accompanied with a corresponding increase in the clay content in the same direction. The protective layer's thickness separating the polluted zone from the unpolluted zone is observed to increase with an average thickness of $4 \mathrm{~m}$. In this region, lithologic unit serving as a protective layer is the sandy clay and clayey sand. The depth extent of saline water pollution in this region is fairly uniform occurring to a depth of about $160 \mathrm{~m}$.

The presence of freshwater sand units having thickness range between 10 and $24 \mathrm{~m}$ is observable in the boreholes. This means that boreholes along the axis would have to be drilled to a depth of about $230 \mathrm{~m}$.

\section{Geosection D-D' (Unity-Lawal Silawal-Ologo)}

Figure 7 shows the correlation panel of LBH2, LBH12 and LBH8 oriented in the approximate northwest-southeast direction. The correlation shows the increase in pollution in the southeastern direction and a sharp increase on getting to LBH8. There is a general increase in clay unit in the southeastern direction, and the protective layer separating the polluted area from the unpolluted area is 


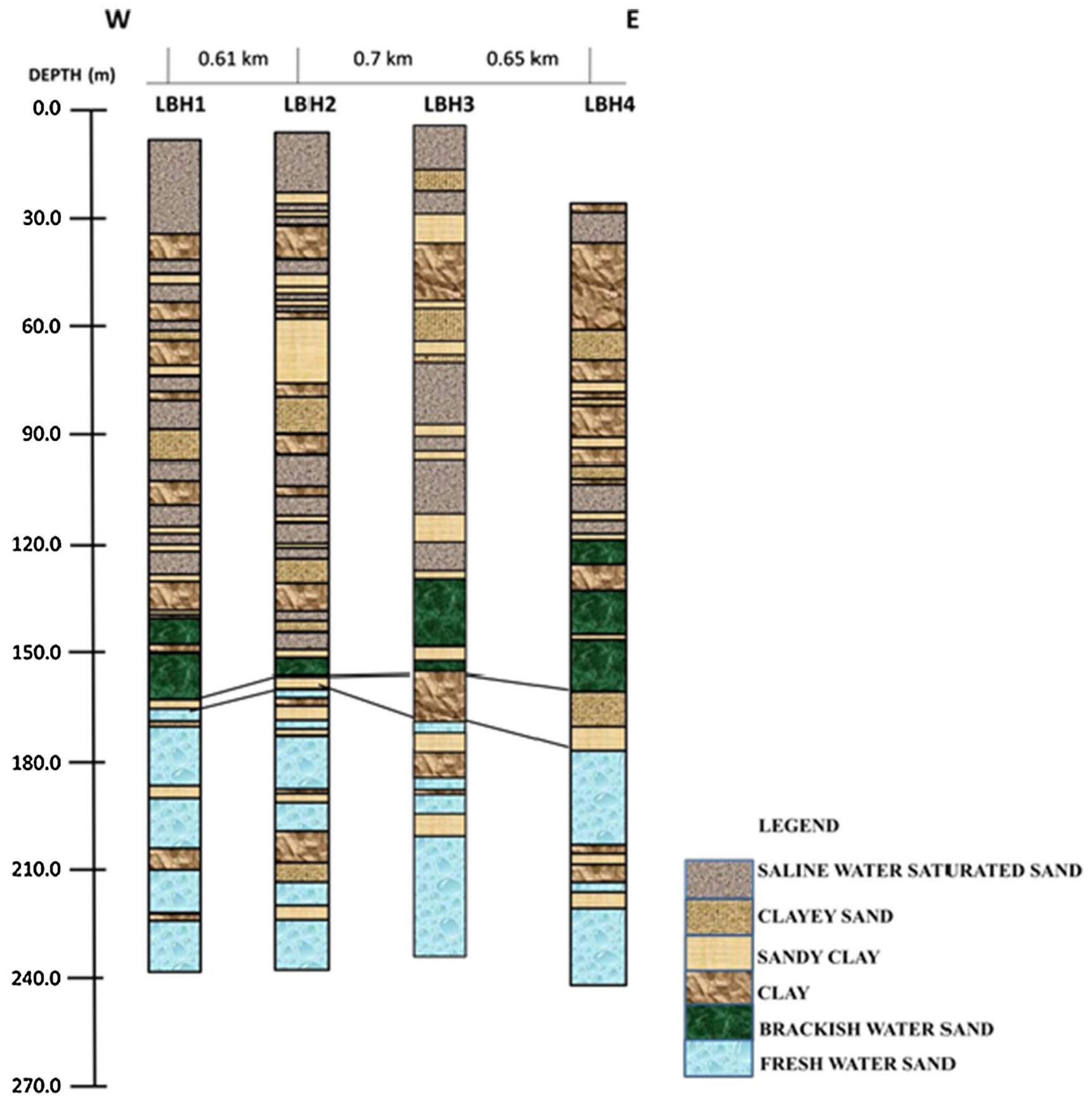

Fig. 6 Correlation panel of geosection $\mathrm{C}-\mathrm{C}^{\prime}$ showing the occurrence of the end of polluted sand unit and the beginning of freshwater sand unit

also increasing in the southeastern direction with its prevalence at LBH8. The protective layers separating the polluted sand units from the freshwater sand are observed to be relatively thin across the boreholes in this region. This makes the freshwater sand in this region to be prone to contamination from saline water in the long run, especially when the boreholes are overpumped.

\section{Geosection E-E' (Akanni Ajiran-Lawal Silawal-Lekki Beach road)}

Figure 8 shows the correlation panel of LBH3, LBH12 and LBH9. The sand unit is prevalent in this zone with its major occurrence at LBH12. This will not pose problems to groundwater developers, especially during the drilling stage. 


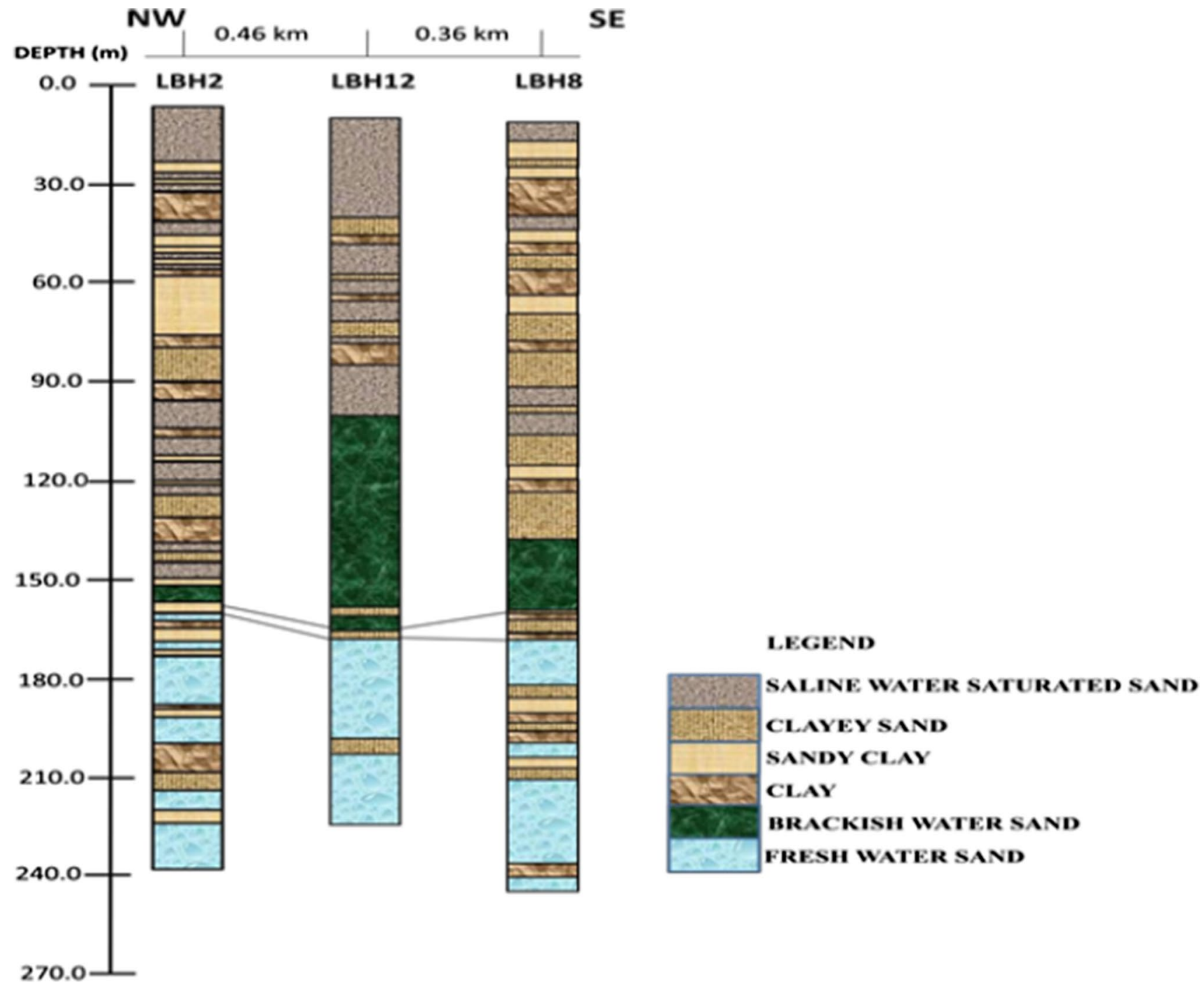

Fig. 7 Correlation panel of geosection D-D' showing the occurrence of the end of polluted sand unit and the beginning of freshwater sand unit

The depth extent of pollution is observed to be fairly uniform in this zone. The protective layer separating the polluted area from the unpolluted area is made of materials ranging from clayey sand to clay with its prominence occurring at LBH9.

\section{Quantitative interpretation of isoresistivity map}

Figure 9 is the map of isoresistivity of Lekki showing the distribution of resistivity obtained from the resistivity $\log$ of the unpolluted zones. High-resistivity contour is observed in the southern to the eastern part of the surveyed area where $\mathrm{LBH} 3, \mathrm{LBH} 4, \mathrm{LBH} 8$ and $\mathrm{LBH} 9$ are located in Lekki axis. This region has relatively high resistivity in the range of 276-327 $\Omega \mathrm{m}$ implying that the water has not been intruded with saltwater. The western flank of Lekki axis shows contour of relatively low to moderate resistivity in the range of 137-212 $\Omega \mathrm{m}$ implying that the region has little concentration of saline water. The low-resistivity contour observed in this region shows that the region is intermediate between saline water and freshwater. The distribution of contour resistivity in the region may be caused by the induced flow of seawater into freshwater as a result of the variation in the thickness of protective layer such as clay over the freshwater sand units as shown in Figs. 6, 7 and 8 on the correlation panel of Lekki axis. The results are similar to the survey carried out in Wellington, New Zealand, where a positive correlation is found to exist between thicker clay units and higher resistivity values (Alger and Harrison 1989). The same was observed for freshwater aquifers in the Canterbury Plains (Broadbent and Callander 1991). However, Osborne (2006) attributed the higher resistivity values for the freshwater sand underlying a thicker clay unit to better control and management of boreholes closer to the coastline. 
NE

SW

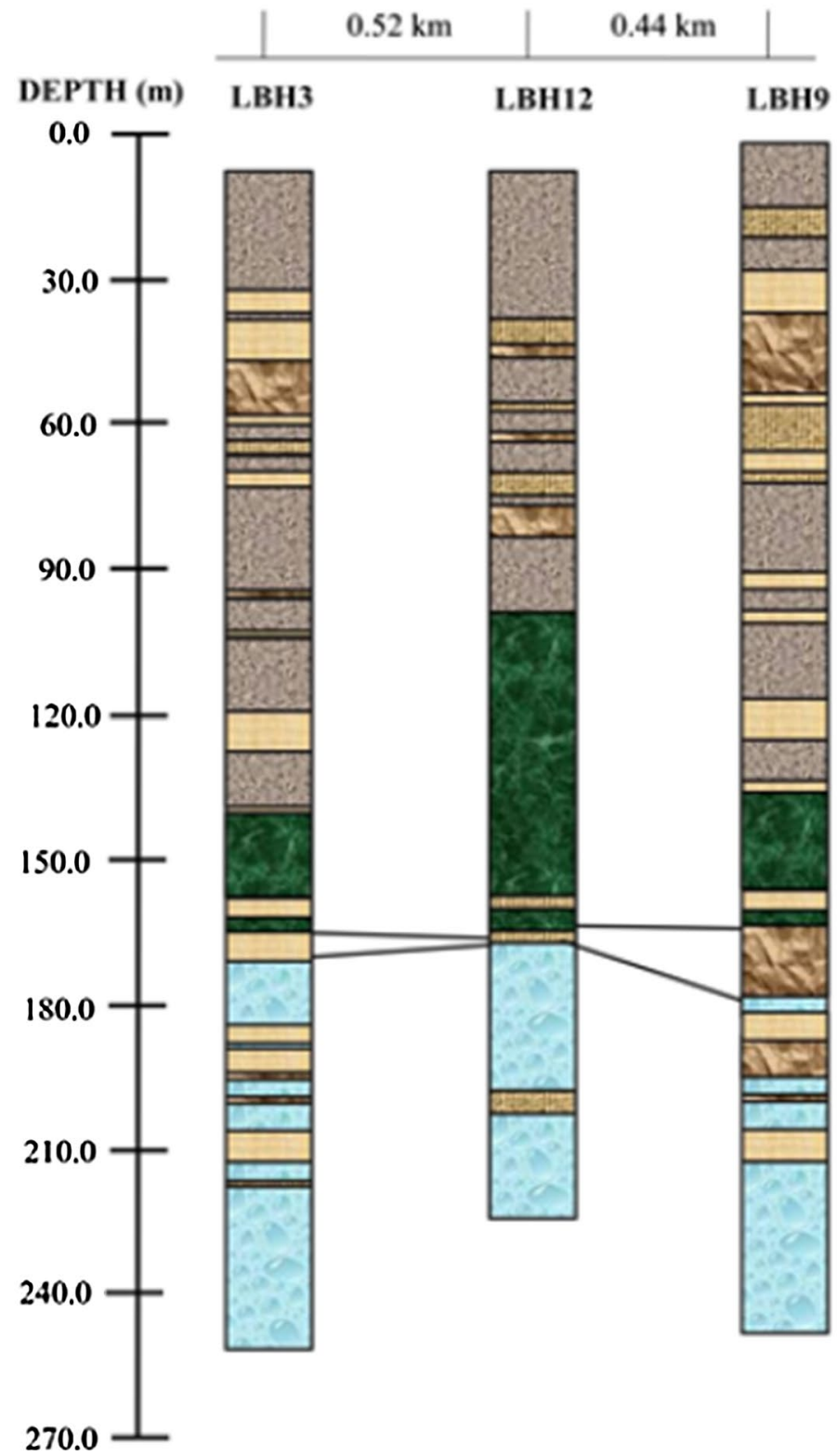

\section{LEGEND}

SALINE WATER SATURATED SAND

CLAYEY SAND

SANDY CLAY

CLAY

BRACKISH WATER SAND

FRESH WATER SAND

Fig. 8 Correlation panel of geosection $\mathrm{E}-\mathrm{E}^{\prime}$ showing the occurrence of the end of polluted sand unit and the beginning of freshwater sand unit

This implies that boreholes located in the southern to the eastern flank of Lekki axis are relatively not susceptible to contamination because of the presence of clay units serving as protective layer over the protected zone and hence the high quality of water in the region indicated by high resistivity values which was also found to be so when Todd and Mays (2005) used a practical field method to estimate groundwater quality in Louisiana from resistivity $\log s$. Boreholes in the western flank of the state are susceptible to contamination because of the relative absence of a thick protective layer in this zone. Therefore, boreholes in this region should be drilled to greater depth than those in the southern and western flank of the axis. Also, water obtained from boreholes in this region should undergo treatment before it is used for domestic use.

Figure 10 is the isoresistivity map of Ikoyi-Victoria Island axis of Lagos metropolis showing the distribution of resistivity of the unpolluted zones. Relatively high-resistivity contour is observed in the western part of the surveyed area where VIBH and VIBH3 are located with resistivity in the range of 248-304 $\Omega \mathrm{m}$. Relatively low-resistivity contour is observed in the eastern and the southeastern flank of the axis where VIBH6, VIBH7 and VIBH4 are located in the range of 153-208 $\Omega \mathrm{m}$. The observed variations in the

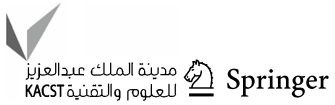




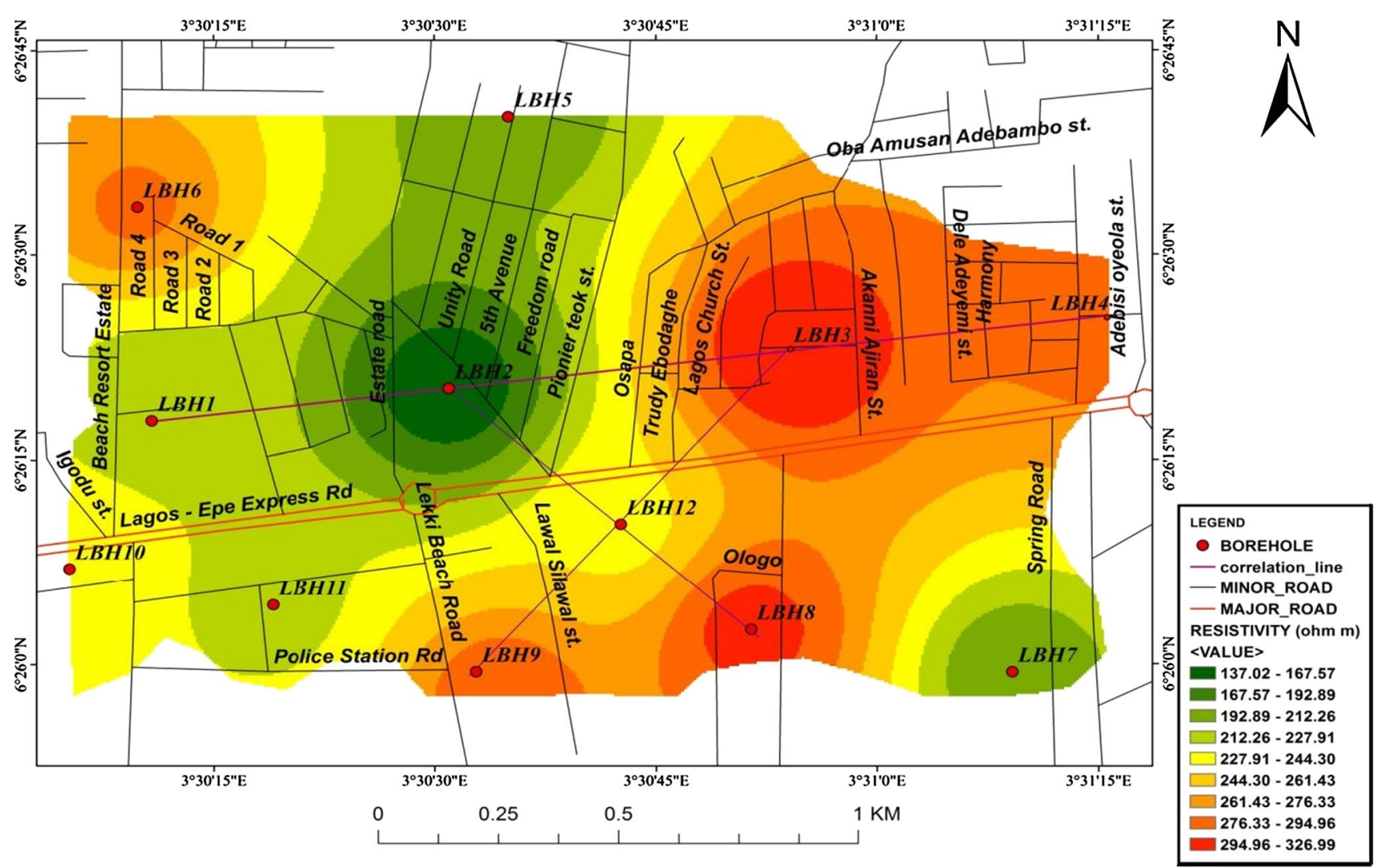

Fig. 9 Isoresistivity map showing the resistivity of the unpolluted zones of Lekki axis

distribution of resistivity in the region could be as a result of varying thicknesses of protecting layers like clay, sandy clay/ clayey sand separating the polluted zones from the unpolluted zones in individual well as shown in Figs. 4 and 5. This implies that boreholes in the western and southeastern flank of the axis would have to be drilled to greater depth so as to prevent contamination of water in the boreholes in this region.

\section{Quantitative interpretation of isopach map}

Figure 11 is the isopach map of Lekki axis showing the distribution of depth extent of the polluted zones. Light blue to blue coloration in the northern section of the zone shows that the depth extent of pollution in the region is low compared to the southern region where the contour coloration is represented by light brown to red, indicating that the depth extent of pollution in the area is high. The depth extent of pollution in the northern flank ranges from 160 to $162 \mathrm{~m}$ while the depth extent of pollution in the southern flank ranges from 164 to $166 \mathrm{~m}$.

Generally, the depth extent of pollution in this axis appears to be in the same range. Therefore, depth within the delineated range of pollution should be generally avoided and boreholes in this axis should be drilled to depth of at least $230 \mathrm{~m}$. This is to establish a reasonable offset and buffer zone from the delineated polluted regions to forestall future contamination of the freshwater aquifers as an offset of $30 \mathrm{~m}$ from the point of contamination to the placement of screens in boreholes at Seeb, and Suwaiq in the Sultanate of Oman was seen to reduce the continuous contamination of the freshwater from saltwater (Al Barwani and Helmi 2006).

Figure 12 is the isopach map of Ikoyi-Victoria Island axis showing the distribution of depth extent of the polluted zones. Very low depth extent of pollution indicated by blue coloration is observed in the northern flank of the region where VIBH1 is located with a depth range of 90-111 m. Red coloration is concentrated in the eastern flank of the axis showing that the depth extent of pollution in the region is high. Similar contour signature is also observed in the western flank of the axis where VIBH3, VIBH4, VIBH5, VIBH6 and VIBH7 are located.

This implies that the depth of boreholes to be drilled in this axis will differ. Boreholes located where VIBH1 and VIBH2 are located can be drilled to a depth of at least $210 \mathrm{~m}$ while boreholes located in the northeastern and southern flank of the axis should be drilled to a depth beyond the 


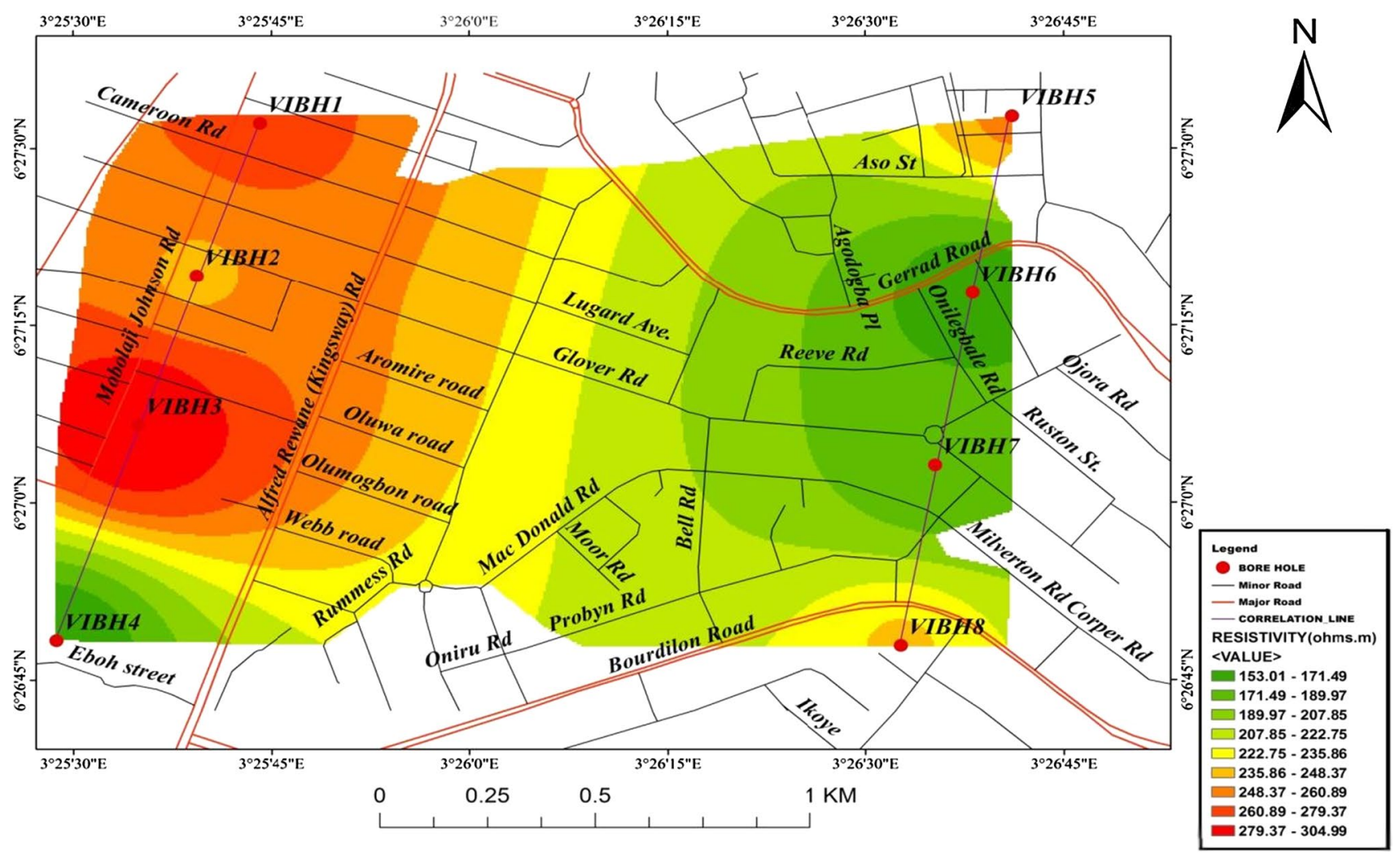

Fig. 10 Isoresistivity map showing the resistivity of the unpolluted zones of Ikoyi Victoria Island axis

polluted zones. Depth of about $220 \mathrm{~m}$ is suggested for boreholes to be drilled in the area.

Generally, variation in the depth extent of pollution in the regions of investigation could be as a result of variation in the level of abstraction of water from boreholes in the regions. The regions investigated are mostly residential areas with the exception of the northwestern part of the region which is a hub for headquarters of financial institutions and corporate companies (Soladoye and Ajibade 2014). The presence of clay unit to inhibit the vertical downward and lateral flow of saline water as observed from the lithologic logs (Figs. 4, 5) could also contribute to the variation in the depth extent of pollution.

The isoresistivity and isopach map shows that some of the aquifer units were found to be strongly impacted by saline water due to incursion from the sea. It was observed that boreholes located in the eastern and southern parts of Lekki, Victoria Island-Ikoyi axis are closer to the coastline. These boreholes are the first contact of saline water incursion. This explains the relatively low resistivity values obtained in these regions. We strongly perceive that daily excessive groundwater extraction has aggravated the saline water incursion in this region and has made it to penetrate into deeper aquifers. This is because most of the locations of the boreholes along the Lekki coastlines are reclaimed peninsula where the lands are sand filled to a thickness of about $25 \mathrm{~m}$ or more (Adepelumi et al. 2009). Furthermore, increase in population which in turn has caused induced flow of saline water into freshwater aquifers by overpumping also contributed in no small measure to the saline water incursion into the aquifer system. The most recent survey carried out in this region showed that the depth extent of pollution averaged $148 \mathrm{~m}$ (Oladapo et al. 2014) while recent studies show that the depth extent of pollution has now increased to an average depth of $156 \mathrm{~m}$. This clearly outlines the danger posed on the sustainable use of freshwater aquifers if the threat of saltwater incursion is not adequately managed.

\section{Borehole design}

The design of the borehole for the areas of investigation is done based on the guidelines of the Lagos State Water Corporation about the placement of screen during borehole development. According to the Lagos State Water Corporation, a buffer zone of at least $30 \mathrm{~m}$ should be established, i.e., the area where the screen should occupy should be at least $30 \mathrm{~m}$ away from the interface between the polluted and the unpolluted zones.

Therefore, based on the guidelines of the Lagos State Water Corporation and the result obtained from the study, 


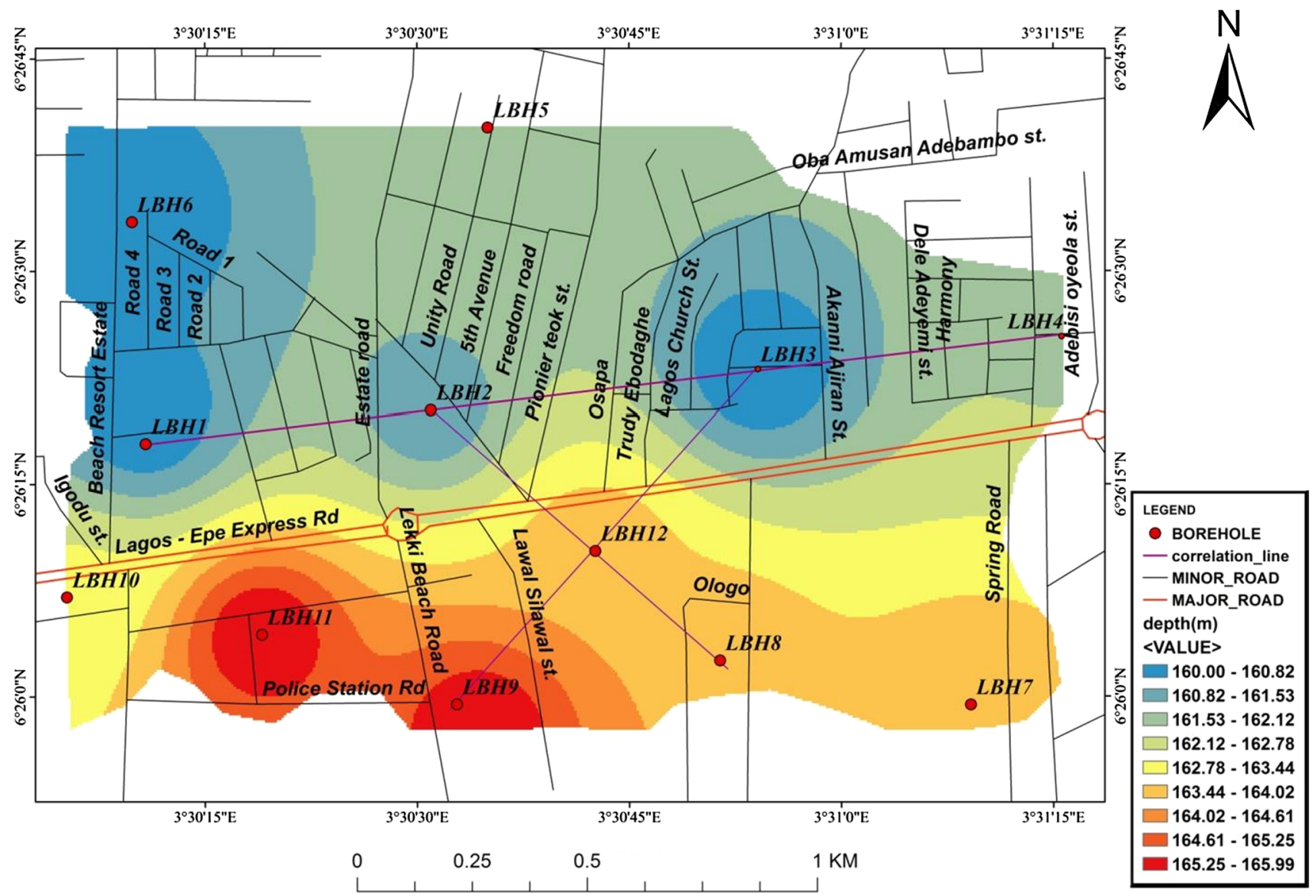

Fig. 11 Isopach map showing the depth extent of the polluted zone of Lekki axis

230-260-m-deep water well can be sunk in Lekki while 220-240-m-deep borehole can be sunk in Ikoyi-Victoria Island axis and a screen length of $12-18 \mathrm{~m}$ should be used depending on the requirement of the client (Figs. 13, 14). Gravel packing should be done to about $50 \mathrm{~m}$ from the well bottom. This is to prevent entrance of sediments into the screen. The borehole should then be well cement grouted to the surface. This is done to prevent flow of contaminants to the fresh aquifer.

\section{Conclusion}

The study was carried out in Lagos Metropolis. The study showed that the subsurface lithology and geologic sequence in Lekki, Ikoyi-Victoria Island consist of intercalation of sand and clay units characteristic of the coastal plain sands.

The aquifer unit in the regions of investigation occurs at different depths. The study showed that the aquifer unit at Lekki and Ikoyi-Victoria Island thickens with depth with a thickness range of 15-22 m. The study also revealed saline water intrusion at Lekki and Ikoyi-Victoria Island axis. The correlation panel for Lekki axis shows that the saline water/ freshwater interface is almost uniform occurring to a depth extent of about $163 \mathrm{~m}$. The correlation panel for Ikoyi-Victoria Island shows variation in the depth of saline water/ freshwater interface between 134 and 156 meters. It was observed that the saline water/freshwater interface increases toward the southern part of the axis.

Furthermore, the study was able to determine the saline water/freshwater interface across the regions investigated. Relatively high resistivity values in the range of 276-327 $\Omega \mathrm{m}$ were observed in the southern to the eastern part of Lekki axis while relatively low moderate resistivity values in the range of 137-212 $\Omega \mathrm{m}$ were observed in the western flank of Lekki axis.

Also, relatively high resistivity values in the range of 248-304 $\Omega \mathrm{m}$ were observed in the western part of Ikoyi-Victoria Island axis while relatively low to moderate resistivity values in the range of 153-208 $\Omega \mathrm{m}$ were observed in the eastern and southeastern flank of Ikoyi-Victoria Island axis. It was concluded that regions having relatively high resistivity values of formation water have thick layer of clay unit serving as a protective layer to 


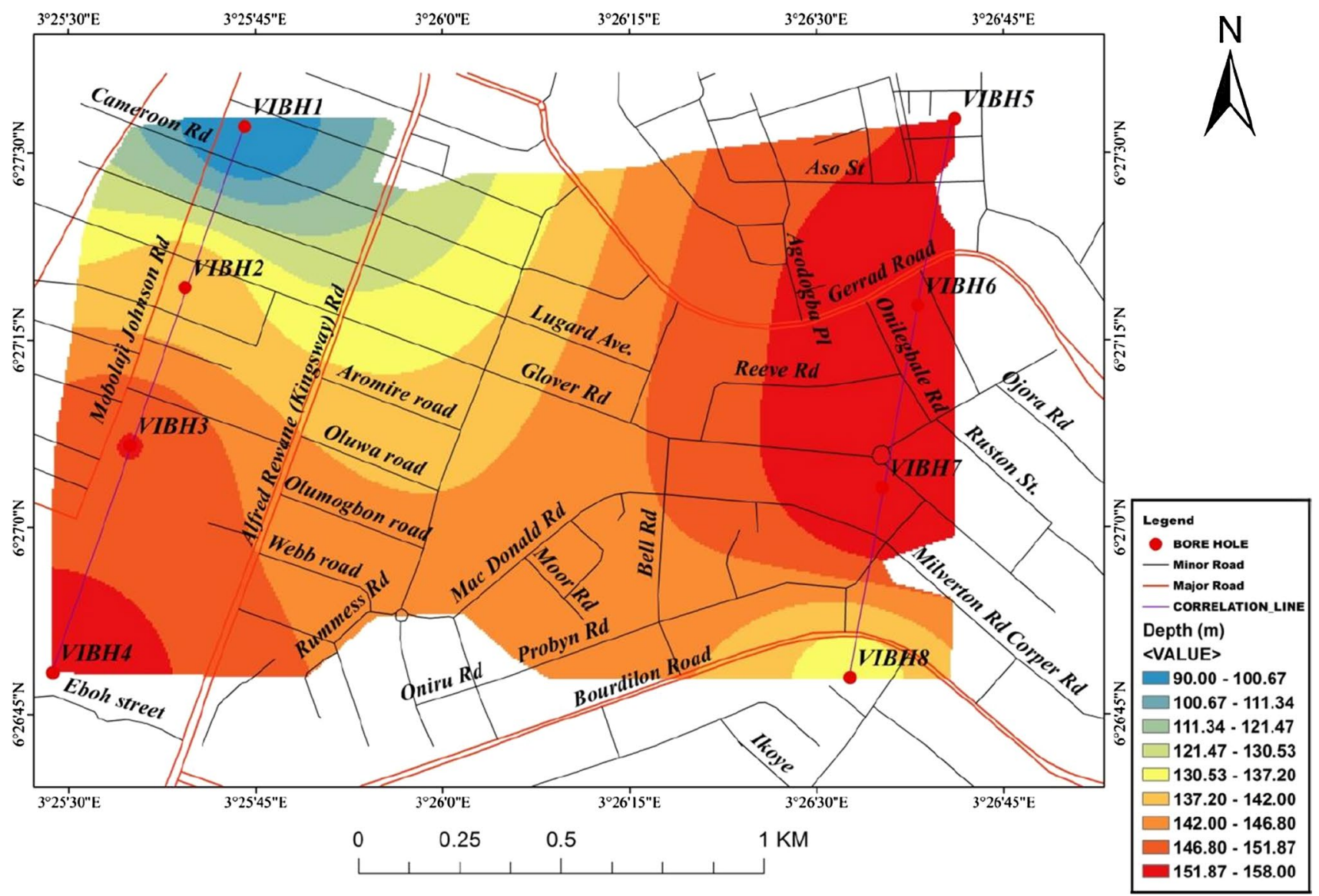

Fig. 12 Isopach map showing the depth extent of the polluted zone of Ikoyi-Victoria Island axis
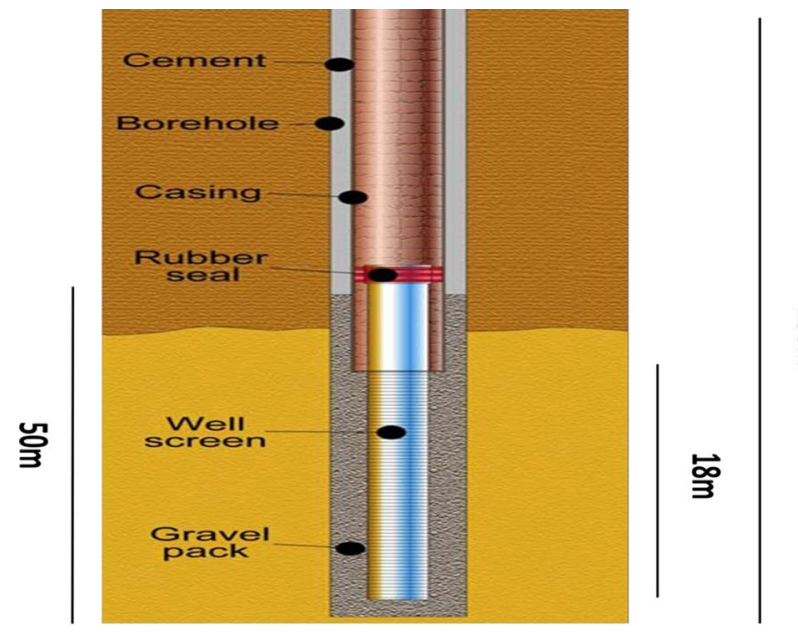

Fig. 13 Borehole design for the surveyed area of Lekki axis

prevent the further infiltration of saline water into freshwater aquifers. Also, the abstraction of water in the areas is minimal as continuous abstraction of water is one of the factors responsible for the induced flow of saline water in freshwater aquifers. Therefore, depth of about $250 \mathrm{~m}$

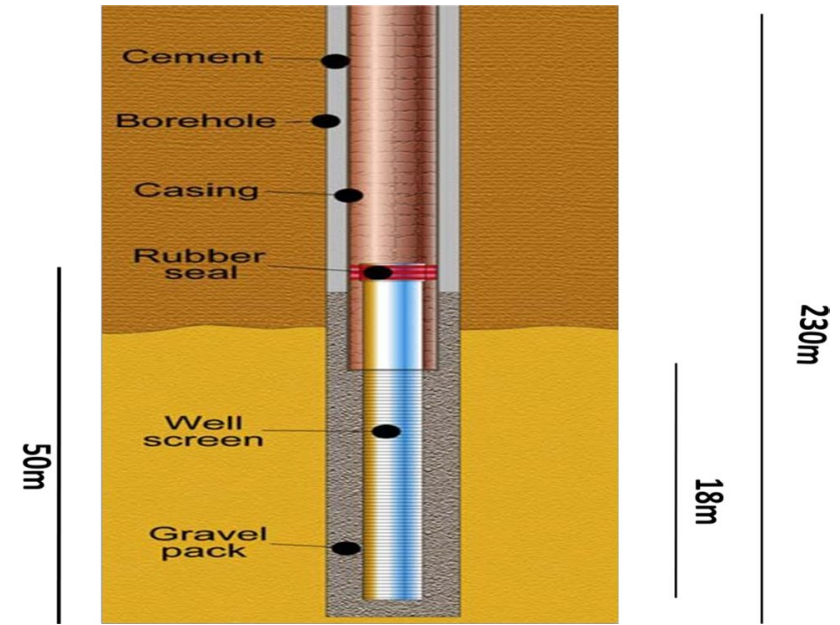

Fig. 14 Borehole design for the surveyed area of Ikoyi-Victoria Island axis

and $230 \mathrm{~m}$ should be drilled for Lekki and Ikoyi-Victoria Island axes, respectively.

Borehole design for Lekki and Ikoyi-Victoria Island axis showed that boreholes drilled should be gravel packed $50 \mathrm{~m}$ 
from the borehole bottom and cement grouted to the surface and buffer zone length of least $35 \mathrm{~m}$ is established between the polluted zone and the placement of screen.

Acknowledgements The authors would like to thank Groundwater and Geophysical Services Limited (GGS) for their cooperation in providing the data.

Open Access This article is distributed under the terms of the Creative Commons Attribution 4.0 International License (http://creativeco mmons.org/licenses/by/4.0/), which permits unrestricted use, distribution, and reproduction in any medium, provided you give appropriate credit to the original author(s) and the source, provide a link to the Creative Commons license, and indicate if changes were made.

\section{References}

Adegoke OS (1977) Stratigraphy and Paleontology of the Ewekoro Formation (Paleocene) of Southwestern, Nigeria. Ann Bull Palaeontol 71(295):357

Adeoti L, Alile OM, Uchegbulam O (2010) Geophysical investigation of saline water intrusion into freshwater aquifers: A case study of Oniru, Lagos State. Sci Res Essays 5(3):248-259

Adepelumi AA, Ako BD, Ajayi TR, Afolabi O, Omotoso EJ (2008) Delineation of saltwater intrusion into the freshwater aquifer of Lekki Peninsula Lagos. Niger J Environ Geol 56(5):927-933

Adepelumi AA, Olorunfemi MO, Falebita DE, Bayowa OG (2009) Structural mapping of coastal plain sands using engineering geophysical techniques, Lagos Nigeria case study. J Nat Sci 1:2

Adeyemi PA (1972) Sedimentology of Lagos Lagoon. An unpublished B.Sc. thesis submitted to the Department of Geology, Obafemi Awolowo University, Ile-Ife, Osun State (Nigeria)

Akomeno UO (2013) Unpublished work Presentation on Coastal groundwater resource-Abstraction, Quality and Related Environment Concerns: Lagos State Case Study. Lagos State Water Regulatory Commission [LSWRC] Workshop June 2013-Groundwater Resources of Lagos State

Al Barwani A, Helmi T (2006) Seawater intrusion in a coastal aquifer: a case study for the area between Seeb and Suwaiq in the Sultanate of Oman. Agric Mar Sci 11:55-69

Alger RP, Harrison CW (1989) Improved freshwater assessment in sand aquifers utilizing geophysical logs. Log Analyst 30:31-44

Allen JRL (1965) A review of the origin and characteristics of recent alluvial sediments. J Int Assoc Sedimentol 5(2):89-191

Awosika LF, Dublin-Green CO (1994) Sand mining in Lagos and Lekki Lagoons. J Min Geol 30(1):137-139

Ayolabi EA, Oyedele KF, Oyeyemi EO, Ewiwile EE (2003) Geoelectric sounding for the determination of groundwater conditions around Iwaya area of Lagos, Nigeria. Glob J Pure Appl Sci 9(4):539-545

Ayolabi EA, Folorunso AF, Odukoya AM, Adeniran AE (2013) Mapping saline water intrusion into the coastal aquifer with geophysical and geochemical techniques: the University of Lagos campus case (Nigeria). Springer Plus 2:433

Barlow PM (2003) Groundwater in Fresh water-salt water environments along the Atlantic seaboard. Phil. Trans R. Soc. (Series B) 241:319-333

Broadbent M, Callander PF (1991) A resistivity survey near Waimakariri River, Canterbury Plains, to improve understanding of local groundwater flow and of the capabilities of the survey method. $\mathrm{N}$ Z J Geol Geophys 34(4):441-453
Chopra P, Papp E, Gibson D (2005) Geophysical and remote sensing methods for regolith exploration. CRCLEME Open File Rep 144:105-115

Coode B, Oteri AU, Rofe KL (1996) Hydrogeological investigation of Lagos State. Final Report, vol. I, II

Custodio E (1987) Groundwater problems in coastal areas. Studies and reports in hydrology. UNESCO, Paris

Fayose EA (1970) Stratigraphic paleontology of Afowo formation. Niger J Min Geol 12:166-171

Fligg K and Rodrigues E (1981) Case histories in the application of geophysical well logging in groundwater investigations. Water resources branch, Ontario Ministry of the Environment, Water Resources Paper, $\mathrm{p} 12$

Goldman M, Kafri U (2004) Hydrogeophysical applications in coastal aquifers. Earth Environ Sci 71:233-254

Gyopari M (2005) Assessment of the seawater intrusion hazard in the Manawatu coastal aquifers and monitoring action plan. Phreatos Limited prepared for Horizons Regional Council, $22 \mathrm{pp}$

Hallenburg JK (1984) Geophysical logging for mineral and engineering applications. Pennwell Books, Tulsa, p 254

Hill MB, Webb JE (1958) The topography and physical features of Lagos harbour: phil. Trans R. Soc. (Series B) 241:319-333

Ibrahim E (2008) Identification of groundwater spreading by using geoelectrical resistivity method. In J Sci Eng Technol 1(3):55-59

Jones HA, Hockey RD (1964) Geology of parts of South-Western Nigeria. Bull Geol Surv Niger 31:56-87

Kampsax-Kruger and Sshwed Associates (1977) Undergroundwater resources of the Metropolitan Lagos, Final Report to Lagos State Ministry of Works, pp 170

Keys WS (1990) Borehole geophysics applied to groundwater investigations. Techniques of Water Resources Investigations, Book 2, Ch. E2, United State Geological Survey, Denver, Colorado

Kwader T (1986) The use of geophysical logs for determining formation water quality. Ground Water 24:11-15

Longe EO, Malomo S, Olorunniwo MA (1987) Hydrogeology of Lagos metropolis. Afr J Earth Sci 6(2):163-174

Nigerian Geological Survey Agency (2009) Airborne Geophysical Survey Residual Magnetic Intensity Map of Ilesa (sheet) Area

Ogbe FGA (1972) Stratigraphy of strata exposed in the Ewekoro Quarry, Southwestern Nigeria. In: Dessauvagie TFJ, Whiteman AJ (eds) African geology. University Press, Ibadan, p 307

Oladapo MI, Ilori OB, Adeoye-Oladapo OO (2014) Geophysical study of saline water intrusion in Lagos municipality. Afr J Environ Sci Technol 8(1):16-30

Omosuyi GO, Ojo JS, Olorunfemi MO (1999) Borehole lithologic correlation and aquifer delineation in parts of the coastal basin of SW Nigeria-implication for groundwater development. J Appl Sci 2(2):617-626

Onwuka OS (1990) Hydrogeology of Lagos State. In: Seminar paper at Nigerian Water Supply Association. pp 33-40

Osborne AM (2006) Movement of water within the Waikanae shallow gravel aquifer and its interaction with the Waikanae River. Unpublished M.Sc. thesis, School of Geography, Environmental and Earth Sciences, Victoria University of Wellington. Wellington. $160 \mathrm{pp}$

Oteri AU (1988) Electric log interpretation for the evaluation of salt water intrusion in the eastern Niger Delta. Hydrol Sci J 33(1/2):19-22

Oyedele KF (2001) Hydrogeophysical and hydrogeochemical investigation of groundwater quality in some parts of Lagos, Nigeria. Afr J Environ Stud 2(1):31-37 
Pareek N, Jat MK, Jain SK (2006) The utilization of brackish water, protecting the quality of the upper fresh water layer in coastal aquifers. Environmentalist 26:237-246

Phongpiyah K, Helmut D (2012) Geophysical logging for groundwater investigations in Southern Thailand. Songklanakarin J Sci Technol 34(4):433-444

Pugh JC (1954) A classification of the Nigerian coastline. J West Afr Sci Assoc 4(3):1-12

Reyment RA (1965) Aspects of the geology of Nigeria. The stratigraphy of the cretaceous and cenozoic deposits. Ibadan University Press, Ibadan, pp 22-73

Schlumberger (1977) Log interpretation/charts. Schlumberger Well Services Inc, Houston

Schnoebelen DJ, Bugliosi EF, Krothe NC (1995) Delineation of saline ground-water boundary from borehole geophysical data. Groundwater 33:965-976
Soladoye O, Ajibade LT (2014) A groundwater quality study of Lagos State, Nigeria. Int J Appl Sci Technol 4(4):271-281

Todd DK, Mays LW (2005) Groundwater hydrology, 3rd edn. Wiley, Hoboken

Geological Map of Lagos State. Nigeria Geological Survey Agency Fact Sheet 68

Publisher's Note Springer Nature remains neutral with regard to jurisdictional claims in published maps and institutional affiliations. 